\title{
PRIORITY AREAS FOR FOREST CONSERVATION IN AN URBAN LANDSCAPE AT THE TRANSITION BETWEEN ATLANTIC FOREST AND CERRADO
}

Keywords:

Landscape metrics

Forest conservation

Urban forest

Priority areas

Index

Histórico:

Recebido 05/05/2016

Aceito 08/08/2016

Palavras chave: Métricas de paisagem Conservação florestal

Floresta urbana

Áreas prioritárias Índice.

Correspondência: kaline.mello@gmail.com

DOI:
ABSTRACT: Urbanization and agriculture growth are some of the major causes of natural ecosystems depletion and biodiversity loss. Conservation efforts can be developed through the prioritization of areas for forest conservation in order to minimize this process. Here, we establish conservation strategies based on a spatial analysis of forest fragments in an urban landscape at the transition between two important Brazilian biodiversity hotspots: Atlantic Forest and Cerrado. A high-resolution mapping of forest patches was used to quantify forest cover and to provide spatial analysis. We developed a Forest Conservation Priority Index (FCPI) derived from landscape metrics to select priority areas for forest conservation efforts. We used area, shape and proximity metrics as landscape structure indicators. Landscape metrics were classified and we attributed a rank and weights for them to calculate the FCPI. Forest covers $17 \%$ of the study area. $60 \%$ of the forest patches comprise less than one hectare, $95 \%$ less than 10 ha and only $1 \%$ more than 50 ha. The largest fragments (> 100ha) are all long and narrow. Also, fewer than half the patches are connected to others. Regions classified as high and very high priority for forest conservation are localized at greater slopes, along rivers and on private lands. Our index allowed the prioritization of forest fragments in an urban landscape, directing efforts of conservation. Creating protected areas and restoration plans are necessary for the better situation of the natural ecosystem. Land-use planning must resolve human demands and conservation of this important ecosystem.

\section{ÁREAS PRIORITÁRIAS PARA CONSERVAÇÃO FLORESTAL EM UMA PAISAGEM URBANA NA TRANSIÇÃO ENTRE MATA ATLÂNTICA E CERRADO}

RESUMO: O crescimento urbano e agrícola é uma das maiores causas de degradação dos ecossistemas naturais e da perda de biodiversidade. Os esforços de conservação podem ser planejados com base na priorização de áreas para conservação florestal de forma a minimizar esse processo. Neste trabalho, nós estabelecemos estratégias de conservação com base em uma análise espacial dos fragmentos florestais em uma paisagem urbana na transição entre dois "hotspots" brasileiros: Mata Atlântica e Cerrado. Um mapa de alta resolução dos fragmentos florestais foi usado para quantificar a cobertura florestal e para fornecer uma análise espacial dos mesmos. Nós criamos um Índice de Prioridade de Conservação Florestal (IPCF) derivado de métricas de paisagem para selecionar áreas prioritárias para esforços de conservação da floresta. Foram utilizadas as métricas de área, forma e proximidade como indicadores de estrutura da paisagem. As métricas de paisagem foram classificadas, atribuindo-se classes e pesos a cada uma para calcular o IPCF. A cobertura florestal representa $17 \%$ da área de estudo, sendo que $60 \%$ dos fragmentos florestais apresentam área menor que um hectare, $95 \%$ são menores que 10 ha e apenas $1 \%$ é maior que $50 \mathrm{ha}$. Os maiores fragmentos (> 100 ha) são alongados e estreitos e menos da metade dos fragmentos são conectados a outros. Áreas classificadas como de prioridade alta e muito alta para conservação florestal estão localizadas em declividades acentuadas, ao longo de rios e em áreas particulares. Nosso índice permitiu a priorização de fragmentos florestais em uma paisagem urbana, direcionando os esforços para a conservação. A criação de Unidades de Conservação e planos de restauração são necessários para melhorar a situação do ecossistema natural. $O$ planejamento do uso do solo deve unir as demandas humanas e a conservação deste importante ecossistema.

' Luiz de Queiroz College of Agriculture - Piracicaba, São Paulo, Brazil

${ }^{2}$ Federal University of São Carlos - Sorocaba, São Paulo, Brasil 


\section{INTRODUCTION}

Natural landscapes have been deeply transformed throughout the world due to urbanization and other anthropic activities. Landscape change has caused the current biodiversity loss crisis and ecosystem services' degradation (WU, 2008). Nonetheless, remnants of natural vegetation within cities may play the role of refuges for plants and animals otherwise maladapted to the urban environment (GODEFROID; KOEDAM, 2003; OLIVER et al., 20II). Green areas and forest fragments in Brazilian cities often have many species of birds, not just those typically common in urban areas, but also those with restricted distributions or even endangered (GALINA; GIMENES, 2006; VALADÃO et al., 2006; SANTOS; CADEMARTORI, 20I0). The importance of species conservation in urban areas is clear because more than half the people in the world live in everexpanding cities (CARREIRO, 2008). In Brazil, for example, over $85 \%$ of people live in urban areas (IBGE, 2010). The two biomes in Brazil that have suffered the most from urban sprawl are the Atlantic Forest and the Cerrado (IBGE, 20I2).

The Atlantic Forest is one of the most important global biodiversity hotspots (MYERS et al., 2000). Its original cover has been reduced by approximately $89 \%$ due to unplanned agriculture and urban sprawl, (RIBEIRO et al., 2009). Cerrado is also a global biodiversity hotspot, and its rapid destruction is due to agricultural expansion especially of soybean (mostly destined for meat production) and more recently sugar cane (for the production of ethanol as a biofuel) (IBGE, 20I2). These two biomes are connected by a seasonally dry tropical forest (SDTF) (HUGHES et al., 20I3) in southeastern Brazil. SDTF is among the most devastated forest types because of its strategic location: low slopes and not far from the coastal zone, where agriculture and urban growth easily occur. In addition, the SDTF is second among the most threatened centers of endemism in the Atlantic Forest, with only $7.1 \%$ of its original cover remaining and $6.8 \%$ of its remaining forest under protection (RIBEIRO et al., 2009).

Prioritizing areas for conservation is the first step to develop strategies to mitigate impacts on biodiversity (VALENTE; VETTORAZZI, 20I I; ARONSON; SASHA, 20I3). By prioritization, we may more effectively target specific resources and direct efforts for environmental policy design. Understanding forest ecosystem structure (i.e. forest composition and configuration) is essential for both forest conservation and restoration projects (VALENTE; VETTORAZZI, 2008; METZGER;
BRANCALION, 20I3). It allows the identification of important factors to maintain local biodiversity and define actions to reestablish landscape functions and ecosystem services.

Landscape metrics have been increasingly used in prioritization to achieve rapid and criterion-based results and are often simpler and less costly than the heretofore use of indicator species (BANKS-LEITE et al., 20II; PEROVIC et al., 20I5; SCHINDLER et al., 20I5). Landscape metrics are used to determine areas of conservation interest and to indicate potentially species-rich areas, and are used in various stages in conservation planning (SCHINDLER et al., 20I3; DE JESUS et al., 20I5), such as to evaluate forest structure changes (del CASTILLO et al., 20I5; BAKER et al., 20I5; OTERO et al., 2015).

Environmental planning based on landscape ecology can generate important information for understanding ecological dynamics and to consolidate management proposals for landscapes with remnants of natural vegetation in areas with ongoing human activities (METZGER; BRANCALION, 20I3).

The general objective of the study is to determine priority areas for forest conservation in an urban landscape. Specific objectives are; (I) to evaluate forest structure based on landscape metrics; (2) to develop a forest conservation priority index; (3) to develop strategies to sustain forest conservation and its ecosystem services in anthropic landscapes.

\section{MATERIAL AND METHODS}

\section{Study area}

The study was conducted in Sorocaba city, located in the southeastern region of the state of São Paulo, Brazil

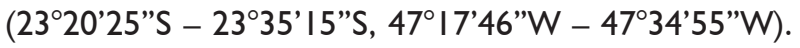
It comprises an area of $\sim 45,000$ ha and an estimated population of 586,625 (in 2010, Figure I). Sorocaba is the most populated city in the Sorocaba and Middle Tietê watershed. With the other nearby major cities (São Paulo, Campinas, Santos and others) it forms the São Paulo Macrometropolis (SILVA; FONSECA, 20I3) comprising one of the largest centers of population in the world, with its associated industries, services, airports and ports, major highways and universities.

Elevation varies slightly, ranging from $535 \mathrm{~m}$ to $1030 \mathrm{~m}$ above sea level. Its forest cover is highly fragmented due to unplanned land use. The region is characterized by transitional vegetation between the Atlantic Forest and the Cerrado, with a predominance of 


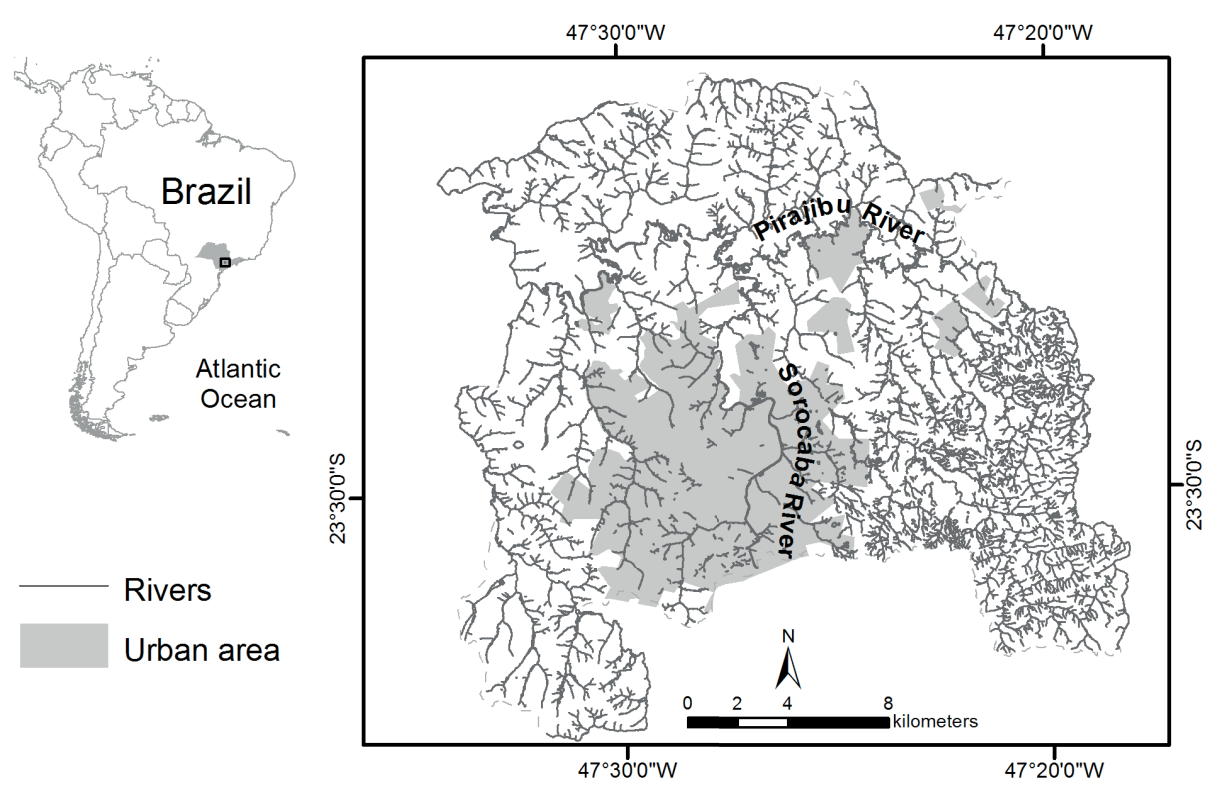

FIGURE I Location of the study area, the city of Sorocaba, state of São Paulo, Brazil, the transition region between Atlantic Forest and Cerrado.

seasonally dry tropical forest (hereafter SDTF). Anthropic transformation of the landscape here was initially due to agricultural development followed by industrialization. Economic growth and proximity to the city of São Paulo (with the largest population of any city in South America) have led the intense conversion of natural landscapes to urban areas, resulting in a matrix of forest patches within the anthropic landscape. With only 17\% of agricultural area, Sorocaba has a high level of urbanization.

\section{Forest mapping}

Forest patches were mapped by digital visual classification by on-screen digitizing of aerial photographs taken in 2006 on a scale of 1:20,000 with $0.4 \mathrm{~m}$ spatial resolution. Prior to mapping, points of interest were recorded in the field using GPS and to differentiate, in aerial photos, between native forests and exotic Eucalyptus and Pinus plantations, citrus crops and Leucaena spp (exotic leguminous). We created a sort key for digital image interpretation based on these known points and image attributes such as tone, texture and shape.

We estimated map accuracy by using an error matrix and the kappa coefficient (CONGALTON; GREEN, 1998). The kappa coefficient indicates classification quality on a scale of 0 to $I$ ( $I$ is perfect). We used 200 points on the image to compare with landuse checking in the field, allowing for determination of errors of omission (when the map omitted something found in the field) and commission (when the map has a feature not found in the field). We obtained a kappa index of 0.8 and so maps were well-representative of the field following Rosner (2006) in which kappa $\geq 0.75$ is considered excellent. Errors of commission were usually due to confusion among growth stages of Eucalyptus spp. Only one error of omission was found. Previous studies showed errors related to the mapping scale. At the $I: 50,000$ scale, the accurate mapping is difficult when patches are smaller than 30 ha, have hillside forests or have easily confused plantations of Eucalyptus spp. and riparian vegetation (RIBEIRO et al., 2009). Our scale ( $1: 2,000)$ allowed accurate mapping of small patches $(<\mathrm{l} h \mathrm{ha})$.

\section{Forest configuration}

Forest configuration was based on calculation of landscape metrics in a Geographic Information System (GIS) environment (ArcGIS version 9.2; ESRI, 2007), using the extension V-LATE I.I (Vector-based Landscape Analysis Tools). $R$ version 2.7.I (R DEVELOPMENT Core Team, 2008) was used for all data processing. We calculated total forest cover and area, shape and connectivity as structural landscape metrics for all forest patches. We chose these metrics based on three ecological concepts. First, island biogeography (MacArthur and Wilson, 1967), in which large areas should have greater environmental variation and consequently greater biodiversity (METZGER, 1999). Second, the edge effect, in which the influence of the adjacent landscape is large and depends on the length and area of the natural forest patches and influences the species composition along the edges (HARPER et al., 2005). Third, in metapopulation dynamics (HANSKI, 1998), with subpopulations separated by gaps or barriers 
and, at times, connected by dispersal, in which the degree of connectivity will facilitate or hinder movement between habitat fragments (TAYLOR et al., 1993). These three metrics are more or less independent concepts and so permit independent analysis.

The shape of a habitat patch determines the extent of its perimeter and area. A circular shape is that which minimizes the perimeter/area ratio and generates edges all equidistant from the patch center. Patch shape was estimated using a shape metric (SHAPE) expressed as given by the following equation $\mathrm{I}$, where, $\mathrm{P}$ is the circumference, $A$ is area and $c$ is a constant. A perfect circle has a SHAPE value of zero, and SHAPE values $\geq 6$ are heuristically considered irregular.

SHAPE $=\frac{P}{\sqrt{\frac{A}{C}}}$

Estimates of fragment isolation and connectivity based on landscape metrics only describe structural relationships among forest patches (structural connectivity; METZGER, 1999). We used the metric PROX which calculates area of all patches within a buffer centered on the target patch divided by the squared distance from it, equation 2 , where, $A$ is area summed over all patches within the buffer, and $D$ is the distance of each one to the target patch summed over all patches.

$\operatorname{PROX}=\frac{\sum \mathrm{A}}{\left(\sum \mathrm{D}\right)^{2}}$

PROX values range from 0 to infinity, in which 0 is when there is only one fragment in the buffer and large values indicate a combination of larger areas with smaller inter-patches distances. We used this metric with four buffer sizes to simulate movement distances over open areas of typical rainforest animals: $50 \mathrm{~m}$ for small birds (AWADE; METZGER, 2008), $100 \mathrm{~m}$ for birds and small mammals (BOSCOLO; METZGER, 2009; FORERO MEDINA; VIEIRA, 2009), $500 \mathrm{~m}$ to $1000 \mathrm{~m}$ for some mammals and insects (TONHASCA-Jr et al., 2003; LIRA et al., 2007).

\section{Priority areas for forest conservation}

We discarded a metric in the analysis when it was strongly correlated with another metric used in the analysis (Table I). Upon examination of buffers, we selected the $100 \mathrm{~m}$ buffer because it is likely to represent a greater number of animal groups in the study area. We also discarded large distances (> $500 \mathrm{~m}$ ) to avoid overestimation of displacement because there are no large mammals in this modified landscape. The metric values were grouped into five classes in order to normalize them for the same equation (below). The values were ranked as follows: one (I) least important, and five (5) most important. Furthermore, each metric received a weight. For the final rank importance for conservation, we proposed the equation 3 Index, named Forest Conservation Priority Index (FCPI), where, FCPI is the forest conservation priority index for each patch, $\mathrm{R}$ is rank and $\mathrm{W}$ is weight (Table 2).

$\mathrm{FCPI}=\frac{\mathrm{R} \cdot \mathrm{W}(\text { AREA })+\mathrm{R} \cdot \mathrm{W}(\text { SHAPE })+\mathrm{R} \cdot \mathrm{W}(\mathrm{PROX})}{\sum \mathrm{W}}$

TABLE I Correlations between patch metrics ( $n=2537)$, including shape (SHAPE), area (AREA) and connectivity (PROX) at four levels $(50,100,500,1000 \mathrm{~m})$.

\begin{tabular}{cccccc}
\hline Variables & AREA & SHAPE & 50 & 100 & 500 \\
\hline SHAPE & 0.52 & - & - & - & - \\
50 & 0.17 & 0.23 & - & - & - \\
100 & 0.20 & 0.22 & 0.97 & - & - \\
500 & 0.20 & 0.21 & 0.95 & 0.98 & - \\
1,000 & 0.21 & 0.22 & 0.95 & 0.98 & 0.99 \\
\hline
\end{tabular}

*All correlations are statistically significant at $\mathrm{P}<0.001$.

TABLE 2 Class, rank and weights of metrics used to calculate forest conservation priority index.

\begin{tabular}{cccc}
\hline Metric & Class & Rank & Weight \\
\hline \multirow{4}{*}{ AREA (ha) } & $0-5$ & I & I \\
& $5.01-20$ & 2 & - \\
& $20.01-60$ & 3 & - \\
& $60.01-120$ & 4 & - \\
\cline { 2 - 4 } SHAPE & $>120$ & 5 & - \\
& $3.51-6$ & $\mathrm{I}$ & 0.7 \\
& $2.51-3.5$ & 2 & - \\
& $1.51-2.5$ & 3 & - \\
& $1-1.5$ & 4 & - \\
& $0-1.89$ & 5 & - \\
PROX (log) & $1.90-4.19$ & $\mathrm{I}$ & - \\
& $4.20-6.39$ & 2 & - \\
& $6.40-8.95$ & 3 & - \\
& $>8.95$ & 4 & - \\
\hline
\end{tabular}

Recent studies suggest that bird diversity in very fragmented landscapes is more strongly influenced by fragment size over connectivity (OLIVER et al., 201 I; MARTENSEN et al., 20I2; DAMI et al., 20I3). On the other hand, small mammals are influenced by fragment size and isolation (VIEIRA et al., 2009). Following guidelines suggested by these and other studies (GENELETTI, 2004; METZGER et al., 2008; RIBEIRO et al., 2009) we assigned greater weight (I) to AREA and W $=0.7$ for SHAPE and PROX, expressed as given by the following equation 4 :

$F C P I=\frac{R(\text { AREA })+0.7 \cdot R(\text { SHAPE })+0.7 \cdot R(P R O X \cdot 100 m)}{2.4}$ 
We established five levels of FCPI: very low (1.0-2.0), low (2.0-2.5), medium (2.5-3), high (3-3.25) and very high $(>3.25)$. Ranges of these classes were determined using Jenks Natural Breaks (an algorithm to maximize similarity of numbers in groups and the distance between groups).

After the priority map, we checked if the public open spaces named as Park in Sorocaba have high priority for conservation. A total of 33 public areas were considered in this analysis.

We validated the FCPI using a sample data and running the index for those fragments. We selected the Areia Branca Watershed, in the North of Sorocaba City, because it presented all classes of priority. Areia Branca stream is a tributary of the Sorocaba River, and its watershed comprises I0I forest fragments. After the simulation, we applied a principal components analysis (PCA) to check the pattern of the FCPI classification and the importance of each landscape metric for Sorocaba city and Areia Branca Watershed. A multivariate analysis of variance (MANOVA) was applied to determine whether there are significant differences between the classes of priority. PCA analysis was carried out in MVSP 3.22 software, whereas MANOVA analysis was carried out using PAST 3.12 software (RENCHER, 2002).

\section{RESULTS}

\section{Forest cover and configuration}

Sorocaba presented a forest cover of 7,509 ha that represents $17 \%$ of the territory. It is distributed in 2,537 patches, of which I,716 are smaller than I ha and which comprise $7 \%$ of the total forest cover (Figure 2). 2,406 fragments are smaller than 10 ha $(95 \%$ of the total of fragments) and they represent $35 \%$ of the total forest cover. Only 24 fragments are $>50$ ha ( $1 \%$ of the total), and 8 of them are $>100$ ha. Fragments $<50$ ha comprise $65 \%$ of the total forest remaining in the study area. All the forest fragments are smaller than 400 ha. The largest patches are 100 to 320 ha (Figure 2).

The forest cover is concentrated in the southeast of the city, where the largest forest patch is located (320 ha). This region is more mountainous and has a large river network (Figure I). In addition, we indicated forest remaining in the North of the city along the Pirajibú River, one of the main tributaries of the Sorocaba River (Figure I). All the fragments in the south and central zones of the study area are $<10$ ha and they are distributed among open spaces within the urban matrix and $<300$ $\mathrm{m}$ from rivers. In general, the largest forest fragments were found associated with the waterbodies.

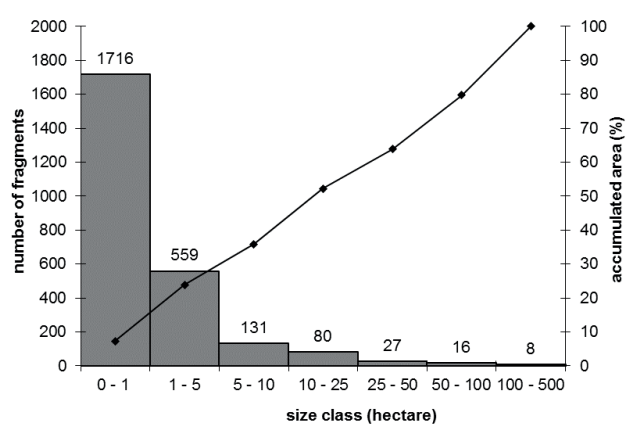

FIGURE 2 Number of forest fragments by size classes and percentage of accumulated area.

Among all fragments, 15 fragments showed a very high SHAPE index $(>6)$ while I,704 showed low values $(<2)$. SHAPE Index near to I indicates patches presenting a shape close to a circle. High values of SHAPE represent complex shapes. Larger patches tend to have complex shapes than the smaller ones (Figure 3, E).

When connectivity was calculated using buffers of $50 \mathrm{~m}$ and $100 \mathrm{~m}$, connectivity was often zero or very near zero and only increased when larger buffers were used $(500-1,000 \mathrm{~m})$. Thus, the relationship between buffer and the value of PROX near zero $(<1)$ was 50:552, 100:317, 500:127 and I,000:53 (Figure 3, A, B, C and D). All the fragments $>50$ ha showed PROX $>$ I for all buffer distances. This means that none of the largest fragments is a patch isolated in the urban matrix.

\section{Priority areas for forest conservation}

According to the forest conservation priority index (FCPI), 330 fragments were classified as very low priority, I,205 as low priority, 595 as medium priority, 300 as high priority and 107 as very high priority (Figure. 4). Fragments of very high priority for forest conservation totaled 2,038 ha, and fragments with high priority, 2,093 ha. Together they represent an area of 4,13 I ha (55\% of total forest cover over all fragments). Fragments of medium priority represent $22 \%$ of the total forest cover, followed by low (16\%) and very low priority (7\%).

Forest patches with high values of importance tend to be eastern, in higher slopes and where rivers are concentrated (Figure 4). Fragments that border the Pirajibú River, in the industrial zone of the city, were very high priority due their size (all of them bigger than 60 ha - Rank 4 and 5) and high connectivity (Rank 5). Only two of the 33 public parks in Sorocaba showed forest patches of very high priority (Mário Covas and Pirajibú). Both are located along the Pirajibú River. Another public area showed high priority for conservation (Brigadeiro Tobias). The remainder of the high priority areas is north and west of the city, on private properties. Most of the 

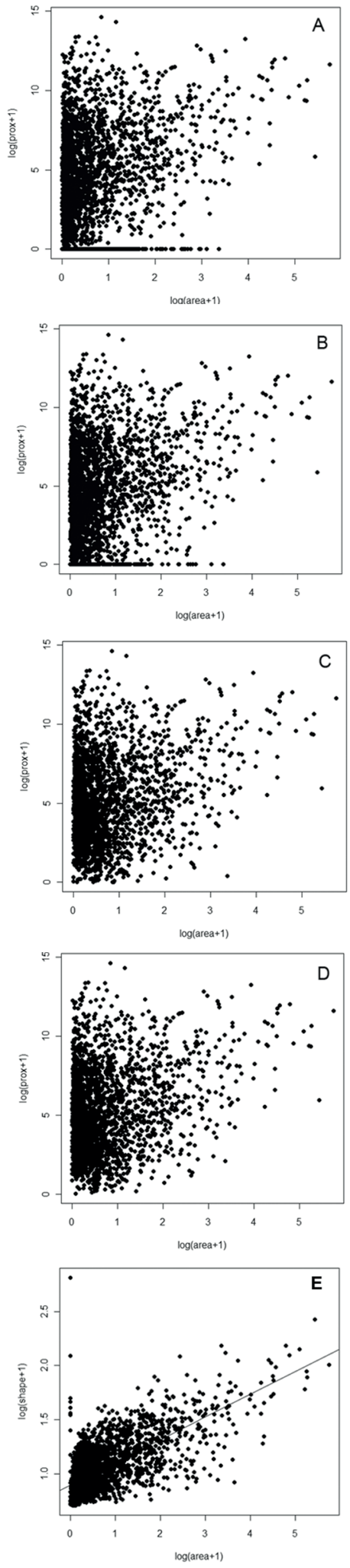

FIGURE 3 Dispersion of forest fragments as a function of the values of the area and connectivity (PROX) using the following buffer values: $A=50 \mathrm{~m}, B=100 \mathrm{~m}, C=$ $500 \mathrm{~m}, \mathrm{D}=1,000 \mathrm{~m}$; and as a function of the values of the area and shape (SHAPE) with a trend line (E).

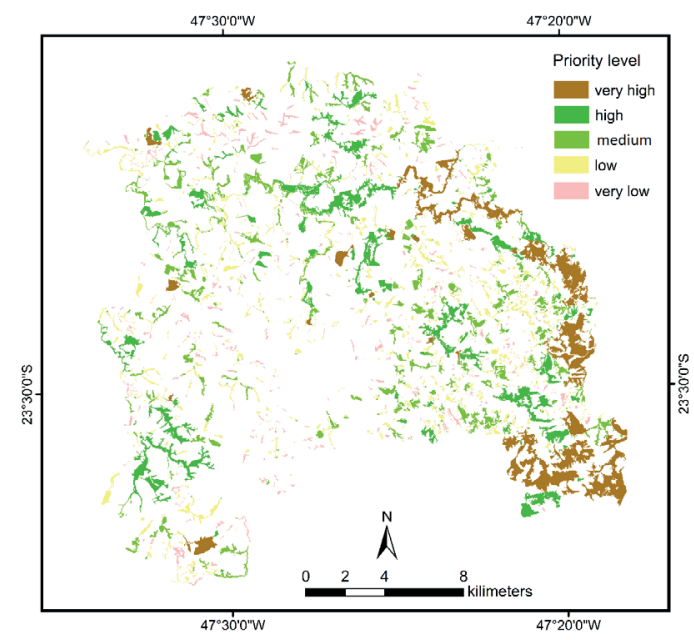

FIGURE 4 Priority areas for forest conservation in the city of Sorocaba, state of São Paulo, Brazil.

public areas showed priority levels between very low and medium.

The PCA analysis showed that FCPI has the same pattern classifying the fragments for all the data and for the sample data in the index validation step (Figure 5). The first two axes of the PCA explained $90 \%$ of the variation for all data (Sorocaba city) and $87 \%$ for the sample data (Areia Branca Watershed). The first axis explained $61 \%$ of the variation for Sorocaba city and $54 \%$ for the Areia Branca Watershed, showing that all the landscape metrics were important for the FCPI. There is a gradient from very low priority fragments to very high. The second axis explained $29 \%$ of the variation for Sorocaba and 33\% for the Areia Branca Watershed, showing that the connectivity is important even when area and shape are not so high. MANOVA tests showed significant difference between all the priority classes for both Sorocaba city (Wilk's $\lambda=0.22$; $F=439$; $P<$ $0.000 \mathrm{I}$ in all cases) and Areia Branca Watershed (Wilk's $\lambda=0.13 ; F=24.66 ; P<0.0001$ in all cases).

\section{DISCUSSION}

Due to fragmentation and habitat loss, the situation is extremely precarious and unless measures are soon taken, this ecotone between Atlantic Forest and Cerrado will be lost. Sorocaba city showed a forest cover close to other cities with the same forest type in the state of São Paulo, Brazil, for example: $17 \%$ of forest cover in Santa Cruz da Conceição and 14\% in São Carlos (FUSHITA et al., 2010; CINTRA et al., 2006), showing a worrying situation of the SDTF. The maintenance of endemic or threatened species found in this area such as Copaifera langsdorffii, Cedrela fissilis and Machaerium villosum of flora, Procnias nudicollis and Urubitinga coronata 


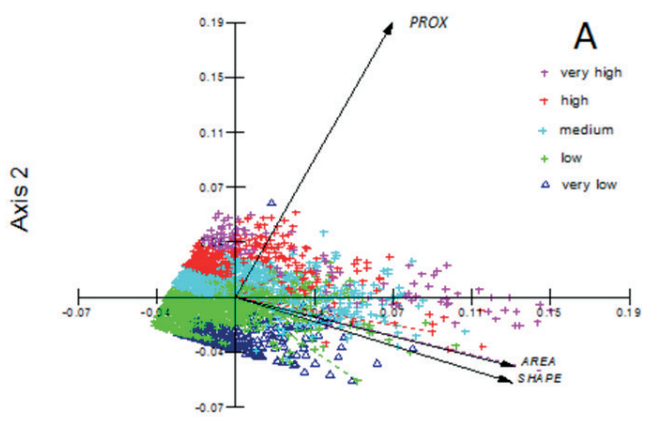

Axis 1

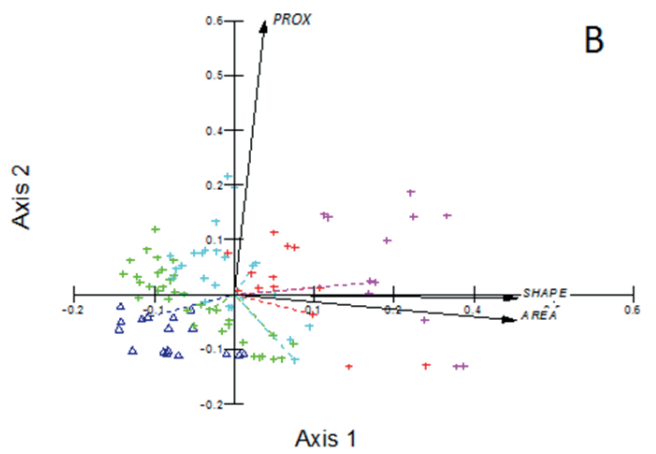

FIGURE 5 Principal components analysis on priority classes for forest conservation relative to the landscape metrics in the city of Sorocaba, state of São Paulo, Brazil for all data (A) and for sample data (B).

of birds, and Monodelphis iheringi of mammals (SMITH et al., 20I4) depends on a conservation strategy.

Landscapes with many small fragments $(<50$ ha, in our case with most forest fragments $<10 \mathrm{ha}$ ), in a heterogeneous matrix, is a typical pattern in the Atlantic Forest (PARDINI et al., 2009, RIBEIRO et al., 2009), Cerrado (VALENTE; VETTORAZZI, 2008; FUSHITA et al., 20I0) and in most fragmented biomes in the word (BODIN et al., 2006). On the other hand, small fragments can be important if they allow a connection among larger remnants. Forest patches $>0.72$ ha can become stepping stones, facilitating the movement of many species (METZGER, 1997). Removal of patches smaller than $\mathbf{5 0}$ ha increases the isolation of the major forest patches and reduces their connectivity (RIBEIRO et al., 2009). Pereira et al. (2010) found that small forest patches ( $<10 \mathrm{ha}$ ) have great values of diversity of tree species in Lavras, Brazil. Strohbach et al. (2009) analyzed neighborhoods with different cover types in an urban area in Germany, and found out that the highest diversity of bird species is related to neighborhoods with a high quantity and quality of green spaces, such as forest fragments, urban parks and riparian forests. In our study, connectivity showed strong importance to determine priority forest fragments, even when area and shape are not so high, showing that the connectivity is an important landscape indicator.

Many forest patches may not support some populations of native flora and fauna because they are too small (up to $400 \mathrm{ha}$ ) and are largely influenced by the urban matrix. However, if corridors exist, or if some dispersal occurs, then these fragments may include meta-population dynamics. A study in the U.S.A. has shown that some forest fragments of 100 to 500 ha, even in highly urbanized areas, have a high diversity of bird species and the inclusion of extensive natural areas in urban landscapes may be the key to the conservation of the biodiversity of migratory and local birds (OLIVER et al., 20II). The larger forest patches that we found for Sorocaba can play an important role for biodiversity conservation. Studies with many taxa in urban landscapes revealed that species composition and richness are directly related to forest patch size (GODEFROID; KOEDAM, 2003; VIEIRA et al., 2009; SANTOS; CADEMARTORI, 20I0; BRÄUNIGER et al., 20I0, SOGA; KOIKE, 20I2; DAMI et al., 20I3). Species richness, when comparing protected areas in urban and rural settings, responds more to fragment size than to the extent of urbanization (KNAPP et al., 2008).

In our study, the largest forest patches are located mainly in peripheral regions to the urban center, at high slopes or in riparian zones. Complex topography often has more mature forests because development and agriculture usually use flatter terrains first (SILVA et al., 2007; ROMPRÉ et al., 2008). Urbanization lasts longer than other types of habitat loss (MCKINNEY, 2002), and the conversion of habitat to urban areas should be seriously debated in the tropics since it may be the most important cause of habitat loss in the future (ROMPRÉ et al., 2008). On the other hand, forest patches with a complex or long shape as riparian zone generate more area under edge effect. Those areas show low tree richness than areas farther from the edge (OLIVEIRA et al., 20I5).

The majority of the remnants are in the remaining rural areas, but some fragments with high and very high priority stand out in the peripheral areas of the city center. They are threatened by urban sprawl, mainly related to property speculation, as occurs in other developing countries (LOPES et al., 200I). Most of these forest patches are on private lands, generating a need for action on the part of the government to work closely with landowners in order to establish better strategies for maintaining these forest patches. One alternative is the creation of Private Reserves of Nature Patrimony, a category of protected area according to the Brazilian 
National System of Protected Areas (law number 9985 of July 18, 2000). The initiatives of private protected areas creation in Brazil are still low, mainly at municipal levels. Municipalities with urban growth in a fragmented biome, besides encouraging the creation of private protected areas, should implement a system of economic valuation and compensation for environmental services provided by private properties as well as laws, tax incentives and funding for biodiversity conservation and reforestation projects. Despite having many laws relating to biodiversity conservation on private property, Brazil still has limited incentives for conservation by landowners.

The FCPI was a strong framework to determine priority areas for forest conservation in an urban landscape, and can be replicated in other cities or watersheds as shown by our results. It is a low-cost alternative for a first step to target resources and direct efforts for forest conservation, once it is simpler and less costly than the use of indicator species (BANKS-LEITE et al., 20II; SCHINDLER et al., 20I5). This approach can direct new studies of biodiversity starting by the priority fragments. The ecosystem conservation across the urban-rural gradient is critical to the long-term environmental health of metropolitan areas in the world, such as the São Paulo Macrometropolis. Urban forests must be incorporated in the planning actions and the management of municipalities, and the FCPI can help decision-makers on environmental policies design.

Once native vegetation areas are increasingly threatened and the number of protected areas is not representative, nature conservation will largely depend on proper management of an anthropogenic matrix (FONSECA et al., 2009; RIBEIRO et al., 2009). According to Ferraz et al. (20/4), the Atlantic Forest cover is actually a heterogeneous mosaic of forests of different ages, situated in different landscape conditions, and thus having different quality levels for biodiversity conservation and ecosystem services provisioning. Tree monocultures (as Eucalyptus spp.) can contribute greatly for conserving biodiversity when maintaining a complex and diverse understory (FONSECA et al., 2009). In rural or urban landscape, educational programs and environmental awareness should accompany all actions for the conservation and restoration by incorporating local people in planning, implementation and monitoring actions. Population support in conservation projects is critical to their success.

Whereas the city's sprawl is an ongoing process, the territorial planning must unite the demands for infrastructure and environmental conservation. Urban and industrial expansion plans should be integrated into the goals of conservation and restoration of natural ecosystems. Urban policies could be the key to more effective conservation of biodiversity and ecosystem services, creating sustainable cities.

\section{CONCLUSIONS}

Sorocaba has a high habitat fragmentation with forest cover distributed in small patches, nevertheless it has priority areas for forest conservation in the transition between the Atlantic Forest and Cerrado.

Forest cover is concentrated at high slopes, riverbanks and on floodplains, predominantly on private lands. Larger forest patches tend to have a complex shape due their location along the rivers. Fewer than half the patches are connected to others.

The proposed index is a strong framework to determine priority areas for forest conservation and it can be applied in other locations. Area, shape and connectivity are good landscape metrics to predict interesting habitat patches and direct efforts for forest conservation in an urban landscape.

Forest management actions must start by the fragments with high and very high priorities for conservation. Creating protected areas and ecological restoration programs are necessary for the better situation of the natural ecosystem, increasing landscape connectivity.

\section{REFERENCES}

ARONSON, J.; SASHA, A. Ecosystem restoration is now a global priority: time to roll up our sleeves. Restoration Ecology, v. 21 , n. 3, p. 293-296, 2013.

AWADE, M.; METZGER, J. P. Using gap-crossing capacity to evaluate functional connectivity of two Atlantic rainforest birds and their response to fragmentation. Austral Ecology, Carlton, v. 33, n. 7, p. 863-87I, 2008.

BAKER, S. R.; BLOOM, N.; DAVIS, S. J. Measuring economic policy uncertainty. The National Bureau of Economic Research, n. 21633, 2015.

BANKS-LEITE, C.; EWERS, R.M.; KAPOS, V.; MARTENSEN, A. C.; Metzger, J.P. Comparing species and measures of landscape structure as indicators of conservation importance. Journal of Applied Ecology, London, v. 46, p. 706-7I4, 20 II.

BODIN, O.; TENGO, M.; NORMAN, A.; LUNDBERG, J.; ELMQVIST, T. The value of small size: loss of forest patches and ecological thresholds in southern Madagascar. Ecological Applications, v. 16, p. 440-45I, 2006. 
BOSCOLO, D.; METZGER, J.P. Is bird incidence in Atlantic forest fragments influenced by landscape patterns at multiple scales? Landscape Ecology, Amsterdam, v. 24, p. 907-918, 2009.

BRÄUNIGER, C.; KNAPP, S.; KÜHN, I.; KLOTZ, S. Testing taxonomic and landscape surrogates for biodiversity in an urban setting. Landscape and Urban Plan, v. 97, n. 4, p. 283-295, 2010.

CARREIRO, M.M. The Growth of Cities and Urban Forest. In: CARREIRO, M.M.; SONG, Y.; WU, J. (Org.). Ecology, Planning, and Management of Urban Forests: international perspectives. Springer, 2008.

CINTRA, R. H. S., SANTOS, J. R., MOSCHINI, L.E. PIRES, J.S.R., HENKE-OLIVEIRA, C. Qualitative and quantitative analysis of environmental damages throw instauration and register of lawful documents. Arquivos de Biologia e Tecnologia, v. 49, p. 989-999, 2006.

CONGALTON, R.G.; GREEN, K. Assessing the accuracy of remotely sensed data: principles and practices. New York: Lewis Publishers, 1998.

DAMI, F.D.; MWANSAT, G.S.; MANU, S.A. The effects of forest fragmentation on species richness on the Obudu Plateau, south-eastern Nigeria. African Journal of Ecology, v. 5I, n.I, p. 32-36, 2013.

DE JESUS, E. N., FERREIRA, R. A., ARAGÃO, A. G., SANTOS, T. I. S., ROCHA, S. L., Structure of forest fragments of the river basin Poxim-SE, as subsidy to ecological restoration. Revista Árvore, v. 39, n.3, p. 467-474, 2015.

DEL CASTILLO, E. M.; GARCÍA-MARTIN, A.; ALADRÉN, L. A. L.; DE LUIS, M. Evaluation of forest cover change using remote sensing techniques and landscape metrics in Moncayo Natural Park (Spain). Applied Geography, v. 62, p. 247-255, 2015.

ESRI. ArcGis, the Complete Geographical Information System. California, USA: Redlands 2007.

FERRAZ, S. F.B.; FERRAZ, K.M.P.M.B.; CASSIANO, C.C.; BRANCALION, P.H.; DA LUZ, D.T.A.; AZEVEDO, T.N.; TAMBOSI, L.R.; METZGER, J.P. How good are tropical forest patches for ecosystem services provisioning? Landscape Ecology, v. 29, p. 187-200, 2014.

FONSECA, C.R.; GANADE, G.; BALDISSERA, R.; BECKER, C.G.; BOELTER, C.R.; BRESCOVIT, A.D.; CAMPOS, L.M.; FLECK, T.; FONSECA, V.S.; HARTZ, S.M.; JONER, F; KAFFER, M.I.; LEAL-ZANCHET, A.M.; MARCELLI, M.P.; MESQUITA, A.S.; MONDIN, C.A.; PAZ, C.P.; PETRY, M.V.; PIOVENSAN, F.N.; PUZKE, J.; STRANZ, A.; VERGARA, M.; VIEIRA, E.M. Towards an ecologically-sustainable forestry in the Atlantic Forest. Biological Conservation, Liverpool, v. I4I, p. I209-1219, 2009.
FORERO-MEDINA, G.; VIEIRA, M.V. Perception of a fragmented landscape by Neotropical marsupials: effects of body mass and environmental variables. Journal of Tropical Ecology, Cambridge, v. 25, p. 53-62, 2009.

FUSHITA, A. T.; ARAUJO, R.T.; PIRES, J.S.R.; SANTOS, J.E. Dinâmica da vegetação natural e das áreas de preservação permanente na paisagem do município de Santa Cruz da Conceição (SP, Brasil), In: SANTOS, J.E.; ZANIN, E.M.; MOSCHINI, L.E. (Eds.), Faces da Polissemia da Paisagem: Ecologia, Planejamento e Percepção. Rima., pp. 193-200, 2010.

GALINA, A.B.; GIMENES, M.R. Riqueza, composição e distribuição espacial da comunidade de aves em um fragmento florestal urbano em Maringá, Norte do Estado do Paraná, Brasil. Acta Scientiarum Biological Sciences, Maringá, v. 28, n.4, p. 379-388, 2006.

GENELETTI, D. A GIS-based decision support system to identify nature conservation priorities in an alpine valley. Land Use Policy, Oxford, v. 21, p. I49-160, 2004.

GODEFROID, S.; KOEDAM, N. How important are large vs. small forest remnants for the conservation of the woodland flora in an urban context? Global Ecology and Biogeography, v. I2, n. 4, p. 287-298, 2003.

HANSKI, I.A. Metapopulation dynamics. Nature, v. 396, p. 4I-49, 1998.

HARPER, K.A., MACDONALD, S. E., BURTON, P. J., CHEN, J., BROSOFSKE, K. D., SAUNDERS, S. C., ESSEEN, P. A. Edge influence on forest structure and composition in fragmented landscapes. Conservation Biology, Washington, v. 19, n. 3, p. 768-782, 2005.

HUGHES, C.E.; PENNINGTON, R.T.; ANTONELLI, A. Neotropical Plant Evolution: Assembling the Big Picture. Botanical Journal of the Linnean Society, v. I7I, p. I-I8, 2013.

IBGE. Instituto Brasileiro de Geografia e Estatística. Atlas Nacional do Brasil - Milton Santos. IBGE, 2010.

IBGE. Instituto Brasileiro de Geografia e Estatística. Indicadores de Desenvolvimento Sustentável. IBGE, 2012.

KNAPP, S.; KUHN, I.; MOSBRUGGER, V.; KLOTZ, S. Do protected areas in urban and rural landscapes differ in species diversity? Biodiversity and Conservation, v. 17, p. 1595-1612, 2008.

LIRA, P.K., FERNANDEZ, F.A.S., CARLOS, H.S.A., CURZIO, P.L. Use of a fragmented landscape by three species of opossum in Southeastern Brazil. Journal of Tropical Ecology, v. 23, p. 427-435, 2007.

LOPES, E.; BOCCO, G.; MENDOZA, M.; DUHAY, E. Predicting land-cover and land-use change in the urban fringe: A case in Morelia city, Mexico. Landscape and Urban Plan, v. 55, p. 27I-285, 200 I. 
MACARTHUR, R.H.; WILSON, E.O. The theory of island biogeography. Princepton University Press, 1967.

MARTENSEN, A.C.; RIBEIRO, M.C.; BANKS-LEITE, C.; PRADO, P.I.; METZGER, J.P. Associations of forest cover, fragment area and connectivity with neotropical understory bird species richness and abundance. Conservation Biology, v. 26, n.6, p. II00-IIII, 2012.

MCKINNEY, M.L. Urbanization, biodiversity, and Conservation. Bioscience Journal, v.52, n. 10, p. 883-890, 2002.

METZGER, J. P.; BRANCALION, P. H. Challenges and Opportunities in Applying a Landscape Ecology Perspective in Ecological Restoration: a Powerful Approach to Shape Neolandscapes. Brazilian Journal of Nature Conservation, v.1I, n. 2, p. 103-107, 2013.

METZGER, J.P. Relationships between landscape structure and tree species diversity in tropical forests of South-East Brazil. Landscape and Urban Plan, v. 37, p. 29-35, 1997.

METZGER, J.P. Estrutura da Paisagem e Fragmentação: Análise Bibliográfica. Anais da Academia Brasileira de Ciências, v. 7I, p. 445-462, 1999.

MYERS, N.; MITTERMEIER, R.A.; MITTERMEIER, C.G.; FONSECA, G.A.B.; KENT, J. Biodiversity hotspots for conservation priorities. Nature, v. 403, p. 853-858, 2000.

OLIVER, A.J., HONG-WA, C., DEVONSHIRE, J., OLEA, K.R., RIVAS, G.F., GAHL, M.K. Avifauna richness enhanced in large, isolated urban parks. Landscape and Urban Plan, v. I02, p. 215-225, 201 I.

OTERO, I.; MARULL, J.; TELLO, E.; DIANA, G.L.; PONS, M.; COLL, F; BOADA, M. Land abandonment, landscape, and biodiversity: questioning the restorative character of the forest transition in the Mediterranean. Ecology and Society, v. 20, n. 2, p. 7, 2015.

PARDINI, R., FARIA, D.; ACCACIO, G.M.; LAPS, R.R.; MARIANO-NETO, E.; PACIENCIA, A. M.L.B.; DIXO, M.; PEROVIĆ, D.; GÁMEZ-VIRUÉS, S.; BÖRSCHIG, C.; KLEIN, A.-M.; KRAUSS, J., STECKEL, J.; ROTHENWÖHRER, C.; ERASMI, S.; TSCHARNTKE, T.; WESTPHAL, C. Configurational landscape heterogeneity shapes functional community composition of grassland butterflies. Journal of Applied Ecology, v. 52, p. 505-5I3, 2015.

OLIVEIRA, L.S.C.; MARANGON, L.C.; FELICIANO, A.L.P.; LIMA, A.S.; CARDOSO, M.S.O.; DOS SANTOS, W.B. Efeito de borda em remanescentes de floresta atlântica na bacia do rio Tapacurá, Pernambuco. Cerne, v.2I, n.2, p.169-174, 2015.

PEREIRA, I.M.; BERG, E.V.D.; PINTO, L.V.A.; HIGUCHI, P.; CARVALHO, D.A. Avaliação e proposta de conectividade dos fragmentos remanescentes no campus da Universidade Federal de Lavras, Minas Gerais. Cerne, v. 16, n.3, p.305-32I, 2010.
R DEVELOPMENT CORE TEAM. A Language and Environment for Statistical Computing. R Foundation for Statistical Computing, 2008. http:// www.R-project.org.

RIBEIRO, C.R.; METZGER, J.P.; MARTENSEN, A.C.; PONZONI, F.j.; HIROTA, M.M. The Brazilian Atlantic Forest: how much is left, and how is the remaining forest distributed? Implications for conservation. Biological Conservation, v. |42, p. I|4I-I I53, 2009.

RENCHER, A.C. 2002. Methods of multivariate analysis, 2nd ed. Wiley.

ROMPRÉ, G.; ROBINSON, W.D.; DESROCHERS, A. Causes of habitat loss in a Neotropical landscape: The Panama Canal corridor. Landscape and Urban Plan, v.87, p. 129-139, 2008.

SANTOS, M.F.B.; CADEMARTORI, C.V. Estudo comparativo da avifauna em áreas verdes urbanas da região metropolitana de Porto Alegre, sul do Brasil. Biotemas, v.23, n. I, p. I8I195, 2010.

SCHINDLER, S.; VON WEHRDEN, H.; POIRAZIDIS, K.; HOCHACHKA, W.M.; WRBKA, T.; KATI, V. Performance of methods to select landscape metrics for modelling species richness. Ecological Modelling, v. 295, p. 107-II2, 2015.

SCHINDLER, S.; WEHRDEN, H.V.; POIRAZIDIS,K.; WRBKA, T.; KATI, V. Multiscale performance of landscape metrics as indicators of species richness of plants, insects and vertebrates. Ecological Indicators, v. 31 , p. $41-48,2013$.

SILVA, G.; FONSECA, M. D. L.São Paulo, city-region: constitution and development dynamics of the São Paulo macrometropolis. International Journal of Urban Sustainable Development, v. 5, n. I, p. 65-76, 2013.

SMITH, W.; MOTA JUNIOR, V.D.; CARVALHO, J.L. Biodiversidade do município de Sorocaba. Prefeitura Municipal de Sorocaba - Secretaria do Meio Ambiente, 2014.

SOGA, M., KOIKE, S. Relative importance of quantity, quality and isolation of patches for butterfly diversity in fragmented urban forests. Ecological resources, v. 27, p. 267-27I, 2012.

STROHBACH, M.W., HAASE, D., KABISCH, N. Birds and the city: urban biodiversity, land use, and socieconomics. Ecology and Society, v. I4 n.2, p. 3I, 2009.

TAYLOR, P. D. FAHRIG, L., HENEIN, K., MERRIAM, G Connectivity is a vital element of landscape structure. Oikos, v. 68, n. 3, p. 57I-573, 1993.

TONHASCA Jr, A.; ALBUQUERQUE, G.S.; BLACKMER, J.L. Dispersal of euglossine bees between fragments of the Brazilian Atlantic Forest. Journal of Tropical Ecology, Cambridge, v. 19, p. 99-102, 2003.

VALADÃO, R.M.; FRANCHIN, A.G.; MARÇAL JÚNIOR, O. A avifauna no Parque Municipal Victorio Siquierolli, zona urbana de Uberlândia (MG). Biotemas, Florianópolis, v. 19, n. I, p. 8I-9I, 2006. 
VALENTE, R.O.A.; VETTORAZZI, C. A. Definition of priority areas for forest conservation through the ordered weighted averaging method. Forest Ecology and Management, v. 256, n.6, p. |408-|4|7, 2008.

VALENTE, R.O.A.; VETTORAZZI, C. A. Multicriteria evaluation in the definition of priority areas for forest restoration, aiming at the sustainable water management. In: BILIBIO, C., HENSEL, O., SELBACH, J. (Eds.). Sustainable water management in the tropics and subtropics and case studies in Brazil. UNIKASSEL, PGCUIt, UFMA, Brazil. p. 377-406, 201 I.
VIEIRA, M.V. et al. Fragment size and isolation as determinants of small mammal composition and richness in Atlantic Forest remmants. Biological Conservation, v. 142, p. I|9|-|200, 2009.

WU, J. Toward a landscape ecology of cities: beyond buildings, trees, and urban forest, In: Carreiro, M.M.; Song, Y.; WU, J. (Eds.), Ecology, Planning, and Management of Urban Forests: international perspectives. Springer, p. 10-28, 2008. 
